\title{
Mariska Koopman-Thurlings, Sylvie Germain. La hantise du mal
}

\section{Emanuele Kanceff}

\section{(2) OpenEdition}

\section{Journals}

\section{Edizione digitale}

URL: http://journals.openedition.org/studifrancesi/9677

DOI: 10.4000/studifrancesi.9677

ISSN: 2421-5856

\section{Editore}

Rosenberg \& Sellier

\section{Edizione cartacea}

Data di pubblicazione: 1 décembre 2007

Paginazione: 697

ISSN: 0039-2944

\section{Notizia bibliografica digitale}

Emanuele Kanceff, «Mariska Koopman-Thurlings, Sylvie Germain. La hantise du mal», Studi Francesi [Online], 153 (LI | III) | 2007, online dal 30 novembre 2015, consultato il 12 janvier 2021. URL: http:// journals.openedition.org/studifrancesi/9677 ; DOI: https://doi.org/10.4000/studifrancesi.9677

Questo documento è stato generato automaticamente il 12 janvier 2021.

\section{(c) $(1) \odot$}

Studi Francesi è distribuita con Licenza Creative Commons Attribuzione - Non commerciale - Non opere derivate 4.0 Internazionale. 


\title{
Mariska Koopman-Thurlings, Sylvie Germain. La hantise du mal
}

\author{
Emanuele Kanceff
}

\section{NOTIZIA}

MARISKA KOOPMAN-THURLINGS, Sylvie Germain. La hantise du mal, Paris, L'Harmattan, 2007, pp. 276 (Coll. «Critiques Littéraires»).

1 Sylvie Germain ha ormai alle spalle una bella carriera di scrittrice, tanto che all'autrice di questo libro può scappare di dire che la scrittrice «compte parmi les plus grands auteurs de notre époque». Nata nel 1954, ha cominciato a scrivere molto presto e ha raggiunto la notorietà con un romanzo d'influenza mistica, Le Livre des Nuits, la cui tematica viene poi ripresa nelle opere successive. Allieva di Emmanuel Levinas alla Sorbona, affascinata dal tema dell'ascesa nella mistica cristiana, non si può dire che sia stata ignorata dalla critica, che nei decenni passati le ha dedicato almeno un centinaio di scritti, su aspetti della sua opera letteraria ma anche del suo pensiero e della saggistica.

2 Tuttavia, era tempo che le venisse dedicato uno studio organico, folto e documentato come questo libro, soprattutto da parte di una studiosa che da molti anni ormai ragiona e scrive sulla sua opera. Mariska Koopman-Thurlings esamina attentamente la parabola creativa di Sylvie Germain attraverso il succedersi dei suoi romanzi e illustra la linea guida della sua ricerca fondamentale, quella che attiene alla presenza del male nel mondo, fino al raggiungimento dell'ascesi che, negli ultimi scritti, permette ai protagonisti di intendere la voce divina attraverso il mormorio della natura. 